\title{
斜板式アキシアルピストンモータの起動・低速時における ピストン〜シリンタホホア間の摩擦力特性*
}

小 林 俊 一** 金 子 力***
池 谷 光 栄**

\section{Friction Force Characteristics between Piston and Cylinder Bore for Startup and Low Speed Operation in Swashplate Type Axial Piston Motors}

\author{
Shunichi KOBAYASHI, Tsutomu KANEKO and Mitsuei IKEYA
}

Principal factors that cause a decrease in the efficiency at startup and in low-speed operation of swashplate type axial piston motors include behavior of sliding parts between i ) slipper and swash-plate, ii) piston and cylinder bore and iii) valve plate and cylinder. Especially, the sliding part between ii) piston and cylinder bore has an influence on the behaviors of the slipper and valve plate.

Several studies has been made on the sliding characteristics between piston and cylinder bore in swashplate type axial piston pumps and motors. However, in those studies, each part of the motor and pump was assumed to be rigid. Therefore, this study has been made to clarify the friction characteristics between the piston and cylinder bore at startup and low-speed operation in swash-plate type axial piston motors, regarding the elasticity of the piston and cylinder. In the simulation analysis, using the finite element method, the stress distribution and deformation of the piston and cylinder, the static frictional force between the piston and cylinder bore with a change in supply pressure, piston tube thickness and static friction coefficient were obtained. As the verification of the simulation analysis and examination in low-speed operation, the static frictional force and the dynamic frictional force between the piston and cylinder bore with a change in the supply pressure and piston tube thickness were measured.

\section{1. 序論}

起動・低速時における斜板式アキシアルピストン モータは，摺動部に適正な潤滑状態を維持せしめるこ とが困難となり，機械効率・容積効率が共に大きく低 下する，その主な原因として，(1)スリッパ〜斜板間, (2)ピストン〜シリンダボア間，(3)シリンダブロック 〜弁板間の 3 簓所の摺動部損失が挙げられる.とりわ け原因(2)に関連し，ピストンとシリンダボア間に作用 する軸方向摩擦力は，スリッパ，シリンダブロックの 挙動を大きく左右するため, 原因(1)，(3)との関連も大 きく，同モータの性能に大きな影響を与えている ${ }^{1}$. よって, ピストン〜シリンダボア間の軸方向摩擦力に 起因する損失の改善を図ることは, 同モー夕の機械・

\footnotetext{
*平成 3 年 3 月 28 日 原稿受付

**長岡技術科学大学工学部

***長岡技術科学大学大学院

(所在地 テ940-21 新潟県長岡市上富岡町1603-1)
}

容積両効率向上策に十分寄与できることが期待される. この観点のもと，ピストン〜シリンダボア間摺動部の 特性解析と性能向上に関し, 従来から数多くの研究が 行われてきた2).しかしこれら研究のほとんどは, ピス トン・シリンダについて, 理論解析は同部を剛体と仮 定し, 実験的研究は同部を剛体と評価して行ったもの であった，従って，より厳密化する上では，同部を弾 性体とする解析および実験結果の評価が必須となって くる.これは高出力化方策の一手法である高圧化に対 処すべき構成部品の弾性変形の考慮についてもぜひ必 要なことである3),4).

上述より，本研究は斜板式アキシアルピストンモー 夕の起動・低速時における性能改善のための技術資料 提供を図ることとして、特にその重要問題箇所の一つ であるピストン〜シリンダボア間の摩擦力を求めるた めに，ピストン・シリンダを弾性体と想定した解析お よび実験により評価, 検証を行う.そのために(1)有限 要素法 (Finite Element Method, 以降, FEMと呼ぶ) による構造解析を応用した，ピストン〜シリンダボア 


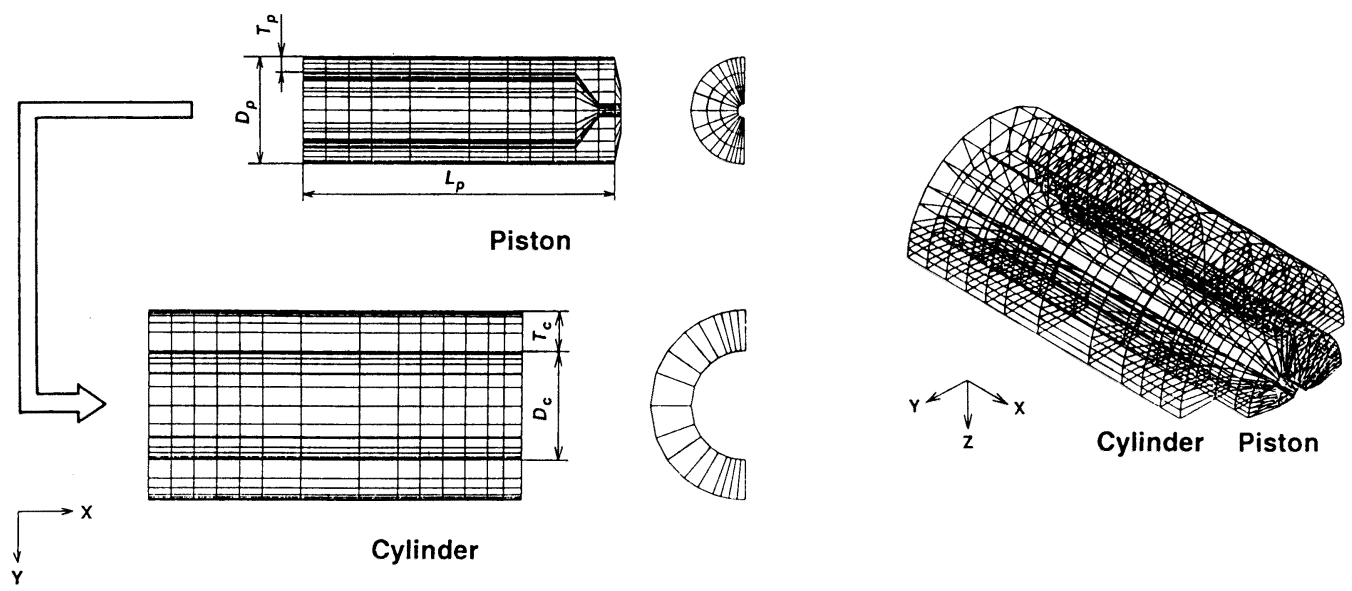

Fig. 1 Finite element mesh of piston and cylinder.

間静摩擦力特性のシミュレーション解析, (2)ピストン 〜シリンダボア間静摩擦力/動摩擦力特性の, 実寸度モ デルを用いた実験による検討を行い, その結果につい て述べる.

\section{2. 主要記号}

$D_{p} \quad$ : ピストン外径

$D_{c} \quad$ : シリンダ内径

$F_{d m a x}$ : 最大動摩擦力

$F_{s}$ : 静摩擦力

$F_{t} \quad$ : ピストン横荷重

$f_{i} \quad$ : ピストン端部とシリンダ肩部の接触部にお ける接触/摩擦要素の支持力

$f_{j} \quad$ : ピストン端部とシリンダ肩部以外の接触部 における接触/摩擦要素の支持力

$K_{s} \quad$ : ばね定数

$L_{c} \quad$ : ピストン長さ

$l_{b} \quad:$ ピストン接触力間の距離

$N$ : 回転速度

$P_{s} \quad$ : 供給圧力

$T_{c}$ : シリンダ肉厚

$T_{p} \quad$ : ピストン肉厚

$\beta$ : 斜板角

$\varphi_{\omega} \quad$ : ピストン位相角 (斜板回転角)

$\mu_{a} \quad$ : ピストン端部, シリンダ肩部の摩擦係数

$\mu_{b} \quad$ : ピストン端部, シリンダ肩部以外の摩擦係 数

\section{3. 解析方法}

\section{1 仮定事項}

解析するにあたり，以下の仮定をおく，

(1) ピストン，シリンダは弾性体である.

（2）斜板とスリッパの影響を無視する.

（3）静止状態で解析を行うため，ピストン端部，シリ ンダ肩部で金属接触が生じ, 解析モデルの単純化を 踏まえてピストン〜シリンダボア間の油膜の圧力は 無視することとする.

（4）ピストン，シリンダの重量は無視する.

\section{2 形状, 要来分割およひ材料条件}

序論で述べた通り, 弾性体と想定したピストン, シ リンダの静的挙動をFEMを適用して解析する. そのモ デルとなるピストン・シリンダの形状および要素分割 をFig. 1に示す.ここではモデルの簡単化のため, $\mathrm{x}-\mathrm{y}$ 平面で面対称とし，ピストン球部を省略して解析を行 う。なお，ピストン球部の省略は，ピストン先端面付 近の応力分布が変化することによってピストン〜シリ ンダボア間の接触面圧に影響を及ぼすが，さほど大き くないため妥当であると考える. 要素は 8 節点 3 次元 立体要素であるが，ピストン〜シリンダボア間は，混 合潤滑領域にあると考えられ，境界条件が非線形にな ることから，同部には接触/摩擦要素を用いた，接触/ 摩擦要素数はピストンの付き出しにより変化するため, 全要素数は464～563，全節点数は1047～1255の範囲で 増減する。また，ピストンには拘束箇所が存在せず剛 性マトリックスが非正定値 ${ }^{5}$ になるため，仮想線形ば ねを取り付けた。このばね定数 $K_{s}$ は応力分布等の計算 結果に影響がないように十分小さな値とした（$K_{s}=$ $\left.1.0 \times 10^{-5}[\mathrm{~N} / \mu \mathrm{m}]\right)$.

計算定数および材料定数を, Table 1, Table 2に示 す. Table 1 において, ピストン肉厚 $T_{p}$ を変化させてい 
Table 1 Principal dimensions of piston and cylinder, swashplate angle.

\begin{tabular}{|lll|c|}
\hline Diameter of piston & $D_{p}$ & {$[\mathrm{~mm}]$} & 23.989 \\
\hline Length of piston & $L_{p}$ & {$[\mathrm{~mm}]$} & 68.5 \\
\hline Piston tube thickness & $T_{p}$ & {$[\mathrm{~mm}]$} & $1.5,3.5,4.5$ \\
\hline Diameter of cylinder & $D_{c}$ & {$[\mathrm{~mm}]$} & 24.005 \\
\hline Cylinder thickness & $T_{c}$ & {$[\mathrm{~mm}]$} & 9.0 \\
\hline Swashplate angle & $\beta$ & {$[\mathrm{deg}]$} & 15.0 \\
\hline
\end{tabular}

Table 2 Material data and calculating constants.

\begin{tabular}{|c|c|c|c|c|c|}
\hline & \multirow{2}{*}{ Material } & \multirow{2}{*}{$\begin{array}{l}\text { Young's } \\
\text { modulus } \\
\text { [GPa] }\end{array}$} & \multirow{2}{*}{$\begin{array}{l}\text { Poisson's } \\
\text { ratio }\end{array}$} & \multicolumn{2}{|c|}{ Friction coefficient } \\
\hline & & & & $\mu_{a}$ & $\mu_{b}$ \\
\hline Piston & $\begin{array}{l}\text { High strength } \\
\text { steel }\end{array}$ & 206 & 0.3 & \multirow{2}{*}{$\begin{array}{l}0.1 \sim 0.7 \\
0.5(\text { Standard })\end{array}$} & \multirow{2}{*}{$\begin{array}{l}0.05 \sim 0.4 \\
0.1 \text { (Standard) }\end{array}$} \\
\hline Cylinder & $\begin{array}{l}\text { High strength } \\
\text { brass }\end{array}$ & 110 & 0.3 & & \\
\hline
\end{tabular}

るが,これは $T_{p}$ がピストンの変形に大きく影響を及ほ すと考えられるためである。本研究においては，市販 品寸法を参考に, $T_{p}=3.5[\mathrm{~mm}]$ を標準ピストン」寸 法と規定する. Table 2の摩擦係数に関しては, 実際に はピストン〜シリンダボア間で局部的にくい込み，か じり等の現象が起こり得るものと予想されるため, 摩 擦計数 $\mu$ を 2 組設定する手法で近似することを試み, ピストン端部とシリンダ肩部の接触/摩擦要素に対し ては $\mu_{a}$, その他の接触状態における接触/摩擦要素に 対しては $\mu_{b}$ とした。ただし,同部の摩擦係数は接触部の 潤滑状態いかんによって大きく変化し，しかも目下の ところ, 十分信頼出来るだけの厳密な值は得られてい ないので, 摩擦係数值を変更してその影響を検討した。 ここで, $\mu_{a}=0.5, \mu_{b}=0.1$ を本研究ににおいては「基準 摩擦係数值」と規定する.

なお，ピストン〜シリンダボア間の半径すきま（8 $[\mu \mathrm{m}])$ は解析結果である変位の精度 $(0.5[\mu \mathrm{m}])$ より も大きいものである。

\section{3 荷重条件, 拘束条件}

ピストンに供給圧力 $P_{s} に$ 相当する分布荷重をピスト ン内部および後端面に与え, その反力に相当する分布 荷重をピストン先端面に $\mathrm{x}$ 軸の負方向に与えた。また， ピストン横荷重 $F_{t}$ を次式で求め, その力, $F_{t}$ に相当する 分布荷重をピストン先端面にy 軸, 正方向に与えた。

$$
F_{t}=\frac{1}{4} \pi D_{p}{ }^{2} P_{s} \tan \beta
$$

拘束条件は, シリンダ外周を完全固定し, 更に $\mathrm{x}-$ $\mathrm{y}$ 平面上の節点には対称性をもたせるために $\mathrm{z}$ 軸方向 に関して変位を固定した。

\section{4 搫摩㨲力部算方法}

ピストン〜シリンダボア間の静摩擦力はFEMの計
算結果から算出した. 静摩擦力 $F_{s}$ は, 接触/摩擦要素の 支持力（同要素にかかる力）より次式で表せる.

$$
F_{\mathrm{s}}=2\left(\mu_{a} \sum_{i=1}^{m} f_{i}+\mu_{b} \sum_{j=1}^{n} f_{j}\right)
$$

ここで, $m$ はピストン端部とシリンダ肩部の接触部に おける接触/摩擦要素数で, $f_{i}$ はその要素の支持力, $n$ は それ以外の接触部における接触/摩擦要素数で, $f_{j}$ はそ の要素の支持力である. ピストン位相角 $\varphi_{\omega}$ に関し, $\varphi_{\omega}=0$ ををピストンが最も奥に入った状態で, $\varphi_{\omega}=$ $180^{\circ}$ を最も突き出した状態とする. 本モデルでは， $\varphi$ ஸ $\geqq 50^{\circ}$ からピストン先端部がシリンダから突き出し

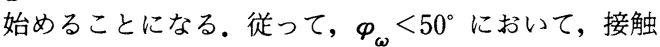
部はシリンダ肩部になく，ピストン先端部にある。ま た, ピストン位相角が $0^{\circ}<\boldsymbol{\varphi}_{\omega}<180^{\circ}$ ではモー夕動作, $180^{\circ}<\varphi_{\omega}<360^{\circ}$ ではポンプ動作を行い, 本研究では モー夕動作のみを解析対象に取り上げる。なお, 摩擦 係数 $\mu_{a}, \mu_{b}$ は, Table 2 計算定数と同値とした.

以上の条件で行う FEMのプログラムは“MARC Ver. K3”（日本マーク）を用いた5).

\section{4. 実験方法}

\section{1 实験装置蛪成}

Fig. 2にピストン摩擦力測定装置の主要構成を, Table 3にその主要寸法を示す6).

本装置は, 斜板回転式で, ピストン本数は 1 本とし ている.ピストン位相角 $\varphi_{\omega}$ は斜板の回転角に応じて定 まる事項であり,ここでは前項で述べた $\varphi_{\omega}$ と同一とな る様に斜板回転角を定める。このことから，本論文で

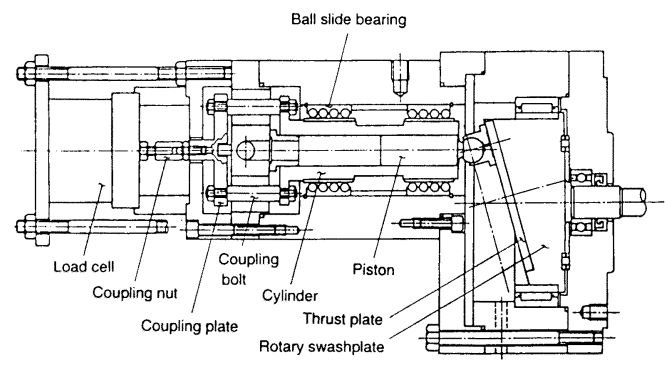

Fig. 2 Schematic diagram of friction force measuring apparatus.

Table 3 Main data of friction force measuring apparatus.

\begin{tabular}{|lll|c|}
\hline Number of piston & $Z$ & 1 \\
\hline Diameter of piston & $D_{p}$ & {$[\mathrm{~mm}]$} & 23.989 \\
\hline Diameter of piston pitch circle & $D_{o}$ & {$[\mathrm{~mm}]$} & 82.0 \\
\hline Swashplate angle & $\beta$ & {$[\mathrm{deg}]$} & 15.0 \\
\hline Theoretical displacement & $V$ & {$\left[\mathrm{~cm}^{3} / \mathrm{rev}\right]$} & 9.9 \\
\hline
\end{tabular}




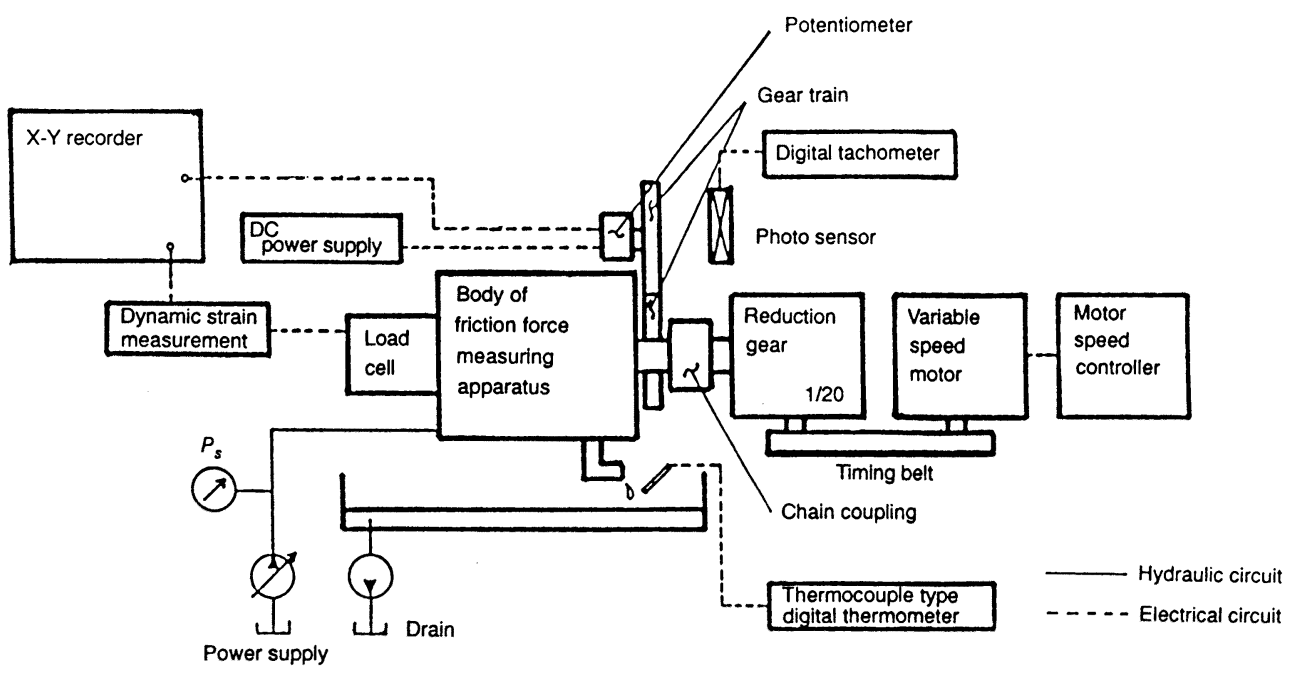

Fig. 3 Block diagram of total experimental system.

は以後, 斜板回転角をピストン位相角 $\varphi_{\omega}$ として表記す る.

ピストン摩擦力測定部は，まずシリンダをボールス ライド軸受によって, 回転方向と軸方向のみ極めて低 荷重で動き得るように支持して後, 連結ボルト, 連結 プレート，連結ナットを経てロードセルに接ぎ，ピス トン〜シリンダボア間に発生した摩擦力をロードセル に伝え，かつ軸方向の動きを止める構造となっている. また, シリンダの回転運動は, 連結プレートと圧力供 給プレート間に組み込んだピンによって止めてある。 Fig. 3に本実験装置の全体構成ブロック図を示す。斜 板から出た駆動軸は, チェーンカップリングにより ウォーム減速機に, 更にタイミングベルトを介して可 变速電動機に接続されている. 従って, モー夕行程時 $\left(0^{\circ} \leqq \varphi_{\omega} \leqq 180^{\circ}\right)$ には可変速電動機によって負荷を掛 けられる状態, ポンプ行程時 $\left(180^{\circ} \leqq \varphi_{\omega} \leqq 360^{\circ}\right)$ には可 変速電動機によって強制駆動される状態となる。

\section{2 計測項目および計測方法}

実験に際して設定した計測項目および計測方法は以 下の通りである。

(a) ピストン〜シリンダボア間の静摩擦力 $F_{s}$, 動摩擦 力 $F_{d}$

ロードセルで検出するが，特に $F_{s}$ は，斜板の回転 を止めた状態からごく微小に回転させたときに検出 される最大值とした。また， $F_{d}$ の最大值を最大動摩 擦力 $F_{d \max }$ として測定した。

(b) ピストン位相角 $\varphi_{\omega}$ 斜板から出た回転軸に歯車列を介して取り付けら

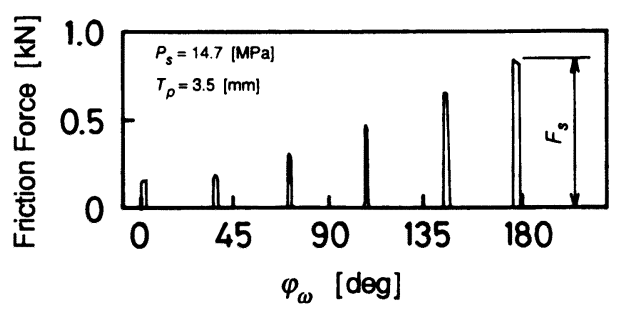

(A) Static friction force $F_{s}$

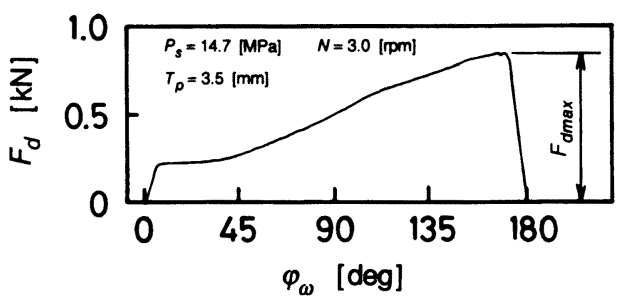

(B) Maximum dynamic friction force $F_{d \max }$

Fig. 4 Typical results of static friction force $F_{s}$ and maximum dynamic friction force $F_{\text {dmax }}$.

れたポテンショメータで検出した。ここで，(a)およ び(b)はXーYレコーダに記録した. Fig. 4に $F_{s}$ ， $F_{d \max }$ の代表的な測定波形を示す。モー夕行程は $0^{\circ}<\boldsymbol{\varphi}_{\omega}<180^{\circ}$ なので, この位相範囲についてのみ 測定した。 $F_{s}$ に関しては $0 \circ$ から $36^{\circ}$ 毎増加させた $\varphi_{\omega}$ において測定した。

(c) 斜板回転速度 $N$

斜板回転軸に接続したウォーム減速機の入力軸回 
Table 4 Experimental conditions.

\begin{tabular}{|lll|c|}
\hline Supply pressure & $P_{S}$ & {$[\mathrm{MPa}]$} & $4.9,9.8,14.7$ \\
\hline Rotation speed & $N$ & {$[\mathrm{rpm}]$} & $0 \sim 5$ \\
\hline Leakage oil temperature & $T$ & {$\left[{ }^{\circ} \mathrm{C}\right]$} & $50 \pm 2$ \\
\hline
\end{tabular}

Table 5 General properties of hydraulic oil

\begin{tabular}{|c|c|c|}
\hline \multicolumn{2}{|l|}{ Viscosity grade } & ISO VG 46 \\
\hline \multicolumn{2}{|c|}{ Relative density $15 / 4^{\circ} \mathrm{C}$} & 0.8717 \\
\hline \multirow{2}{*}{$\begin{array}{l}\text { Kinematic viscosity } \\
{\left[\mathrm{m}^{2} / \mathrm{s}\right]}\end{array}$} & at $37.8\left[{ }^{\circ} \mathrm{C}\right]$ & $47.3 \times 10^{-6}$ \\
\hline & at $98.9\left[{ }^{\circ} \mathrm{C}\right]$ & $6.98 \times 10^{-6}$ \\
\hline
\end{tabular}

転速度をデジタル回転計により計測し，その平均值 を取った。

(d) 供給圧力 $P_{s}$

ブルドン管圧力計によった。

(e) 油温 $T$

ピストン〜シリンダボア間およびスリッパ〜斜板 間から漏れる油の温度と規定し, 熱電対温度計で測 定した。

設定実験条件をTable 4に示す。なお，ピストン・シ リンダ仕様はFEM解析条件 (Table 1, Table 2) と同 様であるが，実験使用品はピストン摺動面に 8 本のラ ビリンス浑を有する、スリッパは最も一般的な油圧平 衡型を用いた。 Table 5に実験で用いた作動油の一般 性状を示す。

\section{5. 解析・実験結果と考察}

\section{1 骤準ピストンを用いた場合}

\section{1 .1 応力分布}

標準ピストンを用いた場合の解析結果であるMises の相当応力等高線図を, Fig. $5\left(\varphi_{\omega}=0^{\circ}\right)$, Fig. 6 $\left(\varphi_{\omega}=180^{\circ}\right)$ に示す.これらより, ピストンの後端部 とシリンダ肩部 $\left(\varphi_{\omega}<50^{\circ}\right.$ ではピストン先端部) の接触 部に応力が集中していることが分る。ここで金属疲労 を防止することによる耐久性の向上，接触面圧を低隇 することによる焼き付き・摩耗の防止，更には静摩擦। 動摩擦力の低滅など，これらの対処策を考虑する上か らは同部への応力集中を緩和することがぜひ必要と考 えられる。

\section{1 .2 静摩擦特性}

Fig. 7に, $\varphi_{\omega}$ と $F_{s}$ との関係を $P_{s}$ をパラメータに示 す。同図より， $P_{s}$ が高いほど $F_{s}$ が大きくなることが分

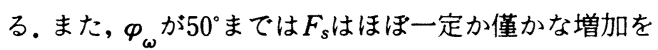
示すが, $50^{\circ}$ からは $F_{s}$ の增加が大きくなる.これは $\varphi_{\omega}$ が $50^{\circ}$ に達するまではピストン先端部がシリンダ内にあ り, シリンダ内ピストン長さに変化は生じないが, $50^{\circ}$

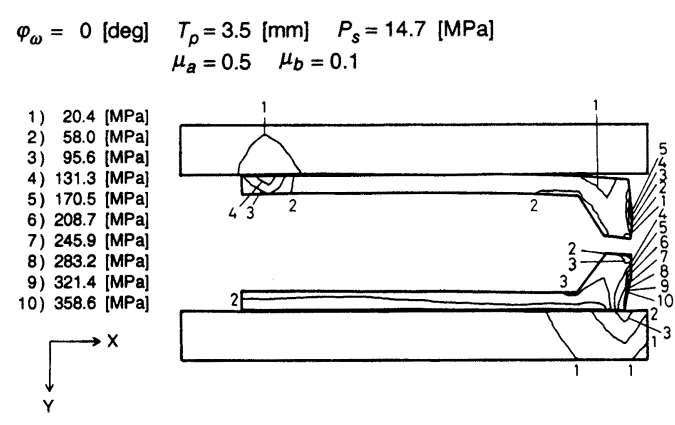

Fig. 5 Equivalent Mises stress contour (Standard piston, $\varphi_{\omega}=0^{\circ}$ ).

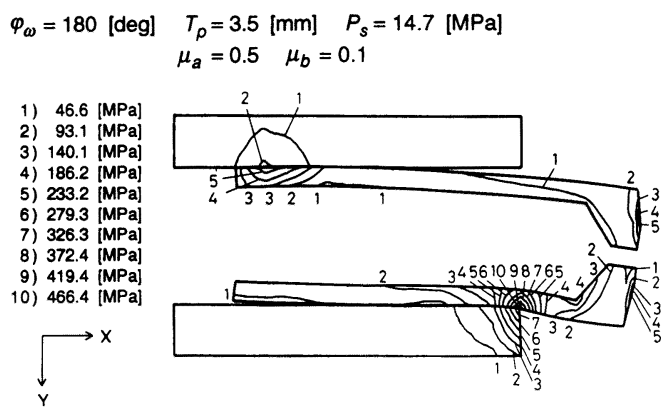

Fig. 6 Equivalent Mises stress contour (Standard piston, $\varphi_{\omega}=180^{\circ}$ ).

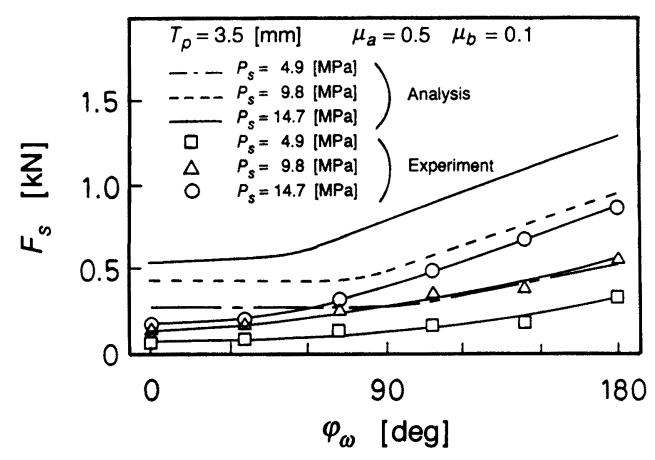

Fig. 7 Relationship between phase angle $\varphi_{\omega}$ and static friction force $F_{s}$

(Standard piston, Analytical and experimental data).

を越えればピストン先端部がシリンダ外に出るため, シリンダ内のピストン長さが减少することから, 斜板 から受ける力の構成分, すなわちピストン横荷重 $F_{t}$ を 支持するピストン端部とシリンダ肩部の接触力が大き

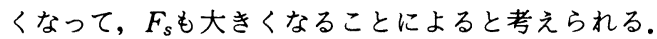




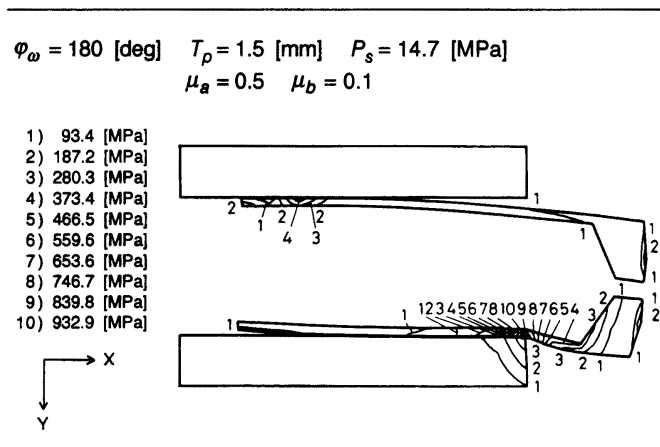

Fig. 8 Equivalent Mises stress contour $\left(T_{p}=1.5[\mathrm{~mm}], \varphi_{\omega}=180^{\circ}\right)$.

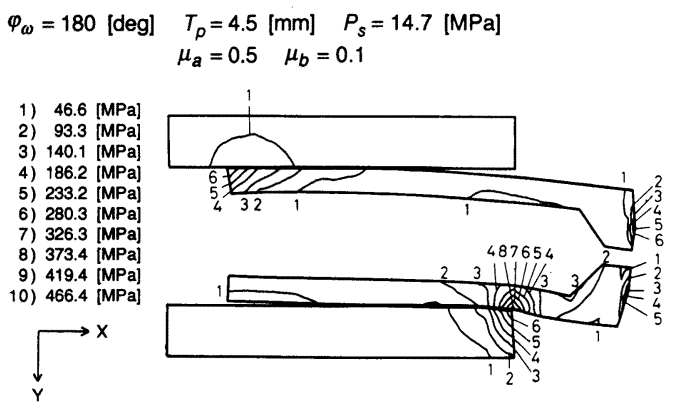

Fig. 9 Equivalent Mises stress contour $\left(T_{p}=4.5[\mathrm{~mm}], \varphi_{\omega}=180^{\circ}\right)$.

また $F_{t}$ は $P_{s}$ により発生し， $P_{s}$ が高いほど $F_{t}$ は大きくな るため, 接触力が增加し $F_{s}$ が大きくなると考えられ る.

また, 実験結果と解析結果を比較すると, 両者は定 性的には良く一致しているが, 解析結果は実験結果よ りも高い值を示していることが分る．この相違の原因 として次の事項が考えられる：(1)FEM解析をする上 でのモデルの分割形状および要素分割数の粗さの影響, (2)FEM解析する上で無視したピストン〜シリンダボ ア間の油膜の影響, (3)摩擦係数の選択の影響, (4)実験 で使用したピストンのラビリンス溝の影響, (5)FEM解 析モデルにおけるピストン球部とスリッパの省略の影 響，(6)実験装置（特にボールスライド軸受）の摩摖に よる影響. 特に原因事項(2) (4)は式(2)の接触力 $f_{i}, f_{j}$ に 影響を及ぼすものと考えられる。なお，このように解 析結果が全体的に高い值を示す傾向は, 次項以降の結 果にも同様に現れるが，これらも上記理由によるもの と考えられる。

\section{2 ピストン肉厚の影需}

\section{2 .1 応力分布および変形量}

Fig. 8, Fig. 9にピストン肉厚 $T_{p}$ を変化させた場合

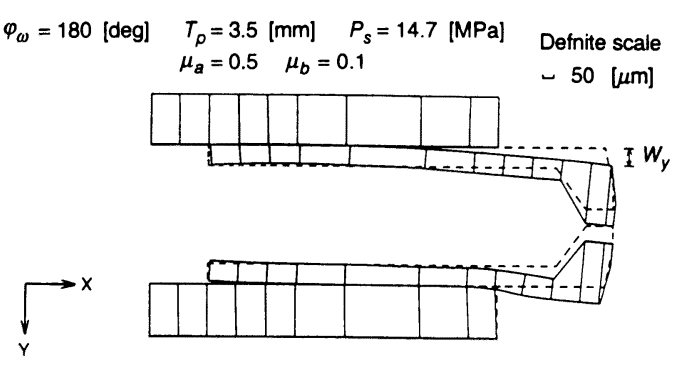

Fig. 10 Exaggerate deformation (Standard piston, $\varphi_{\omega}=180^{\circ}$ ).

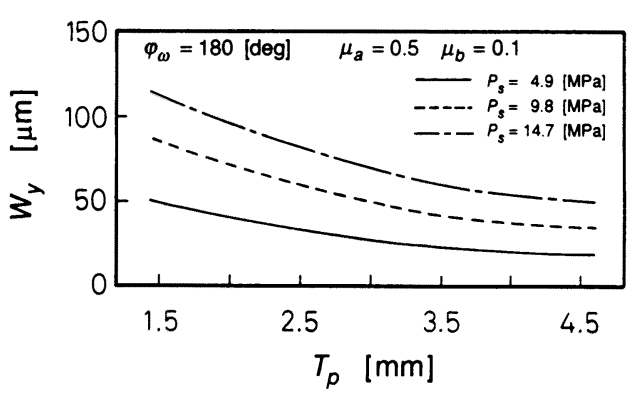

Fig. 11 Relationship between piston tube thickness $T_{p}$ and desplacement of piston head $\mathrm{W}_{y}$ (Standard piston, Analytical data).

の相当応力等高線図を示す. 同図より, $T_{D}=4.5[\mathrm{~mm}]$ の場合, ピストン端部での応力集中がピストン後端部 で起きているが, $T_{p}$ が小さくなる程その応力集中が起 きる部分が先端側に位置する傾向があることが分る。 これは，T磁小さくなるほど変形量が増加するためで ある. Fig. 10に変形の一例を示す. 同図中のピストン 先端部の変位量 $W_{y}$ について， $T_{p}$ との関係を示すと Fig. 11の様になる.同図より $T_{p}$ が小さいほど変位量が 増加することが分る。

\section{2 .2 静摩擦特性}

Fig. 12 に $\varphi_{\omega}$ と $F_{s}$ との関係を $T_{p}$ をパラメー夕に示す. 高位相角範囲 $\left(\varphi_{\omega}>80^{\circ}\right)$ の場合, $T_{p}$ が大きいほど $F_{s}$ が

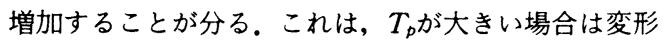
が生じにくく, ピストン端部, シリンダ肩部での応力 集中が大きくなり，〈い込み，かじりの現象が発生し ているためと考えられる。

しかし， $\varphi_{\omega}$ が低い範囲における $T_{p}=1.5[\mathrm{~mm}]$ のピ ストンについて, 解析結果では他のどのピストンより も $F_{s}$ が高くなっており, 実験でも $T_{p}=2.5[\mathrm{~mm}]$ のピス トンより大きくなる。これは次に示すピストンの変形 状況から予想される. (1)ピストンは $T_{p}$ が小さいと变形 


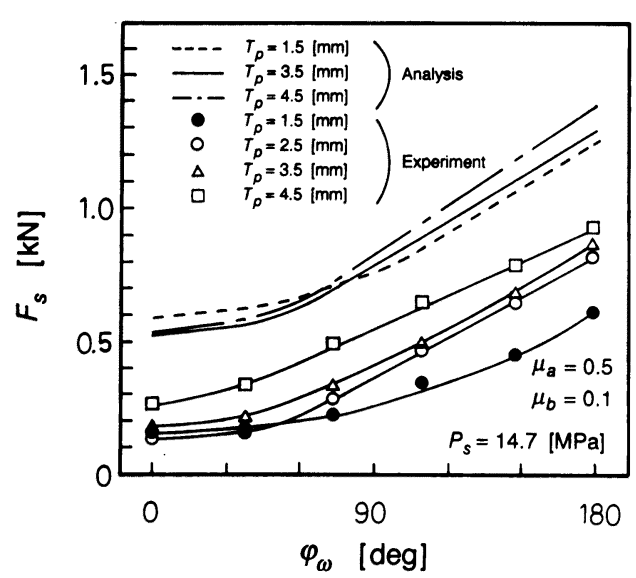

Fig. 12 Relationship between phase angle $\varphi_{\omega}$ and static friction force $F_{s}$ $\left(T_{p}=1.5[\mathrm{~mm}] \sim 4.5[\mathrm{~mm}]\right.$, Analytical and experimental data).

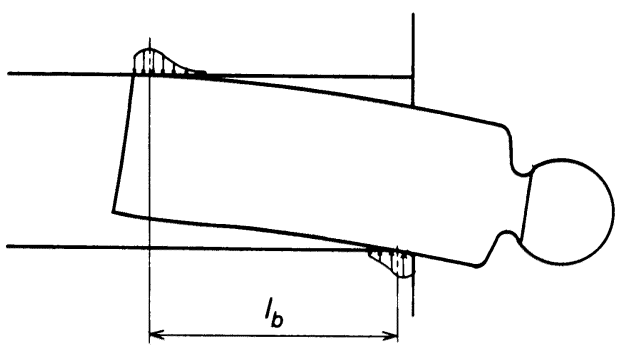

Fig. 13 Distance between two contact forces, $l_{b}$.

を起こし易く, ピストン接触力間の距離 (Fig. $13 の l_{b}$ ) は短くなる．従ってカとモーメントの荷重バランスか ら,それぞれの接触力の増加が考えられる。(2)ピスト ン先端部に関しては構造上 $T_{p}$ に変化がなく,ピストン 先端部がシリンダ内にある位相角範囲 $\left(\boldsymbol{\varphi}_{\omega}<50^{\circ}\right)$ では 変形がピストン先端部では小さく, 主にピストン後端 部で発生. (3)上記 2 事項より, $l_{b}$ が短くなって接触力が 增加し, 特に変形が生じにくいピストン先端部におい て接触力が集中して增加するため, 静摩擦力 $F_{s}$ が他の $T_{p}$ のピストンより大きくなる。

\section{3 摩探俰数の影毒}

シミュレーション解析結果の例として,Fig.14に摩 擦係数 $\mu_{a}$, Fig. 15に摩擦係数 $\mu_{b}$ を変更した場合の $F_{s}$ の 変化を示す. $T_{p}=1.5[\mathrm{~mm}]$ の条件下での $F_{s}$ は, $\mu_{a}$ が小 さい場合， $T_{p}$ が大きいものより高くなるが， $\mu_{a}$ を大き くするに従い $F_{s}$ は低くなる，また逆に， $\mu_{b}$ が大きくな るに従い $T_{p}=1.5[\mathrm{~mm}]$ の $F_{s}$ は大きくなる。これは, $T_{p}=1.5[\mathrm{~mm}]$ に関して, 全接触力は大きいが, ピスト ン端部およびシリンダ肩部上の接触力については他の T値のピストンょりも小さくなっているためである.

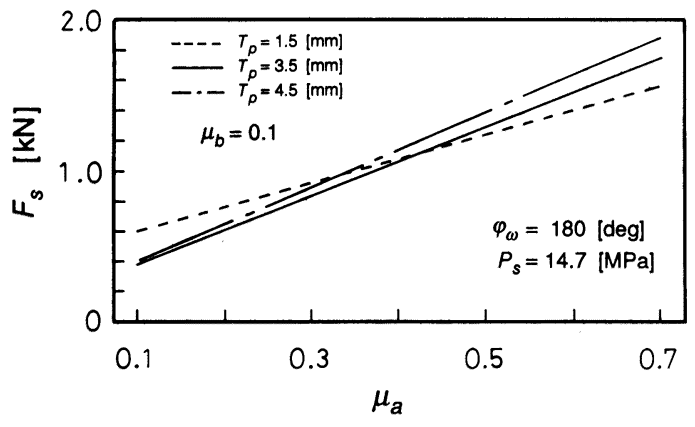

Fig. 14 Relationship between friction coefficient $\mu_{a}$ and static friction force $F_{s}$ (Analytical data).

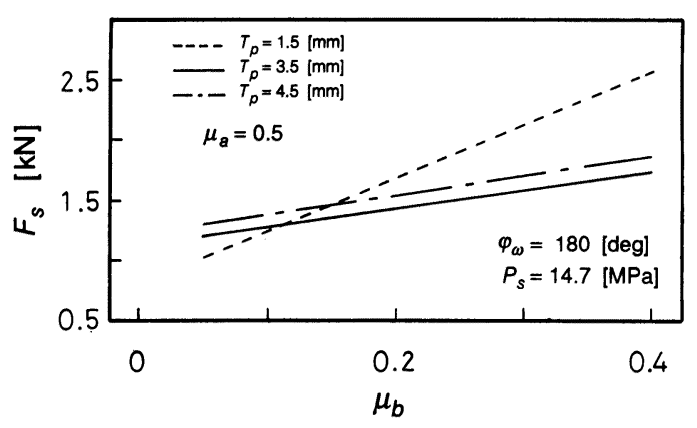

Fig. 15 Relationship between friction coefficient $\mu_{b}$ and static friction force $F_{s}$ (Analytical data).

これは $T_{p}$ が小さいために変形が起こり易く, 接触面積 が増加して, ピストン端部およびシリンダ肩部の応力 集中が緩和されたものと考えて説明出来る． $T_{p}=$ $3.5[\mathrm{~mm}]$ と $T_{p}=4.5[\mathrm{~mm}]$ を比較しても, Fig. 15では 增加傾向の差がほとんどないが, Fig. 14においては僅 かに差があることから，ピストン端部およびシリンダ 肩部上の接触力に差が生じていることが考えられる. この傾向は, 更に高圧力の条件下ではより明確に現れ ると予想される。

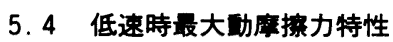

実験例として, Fig. 16に回転速度 $N$ と最大動摩擦力 $F_{d \max }$ の関係を示す．同図より $N$ が増加するほど $F_{d \max }$ が隇少することが分る。これは, ピストン〜シリンダ ボア間は混合潤滑状態にあり, 接触部間に僅かに油膜 が形成されているが、高速になるに従ってこの油膜形 成域が増大し, 潤滑状態が良くなるためと考えられる. 特に $T_{p}=1.5[\mathrm{~mm}]$ のようにピストン肉厚が小さい場 合には, 全体的に $F_{d \max }$ が低く, Nの増加に伴う $F_{d \max }$ の減少傾向が明確に現われる。これはピストンの変形 量が大きく, 接触力の集中が緩和されて油膜が形成し 


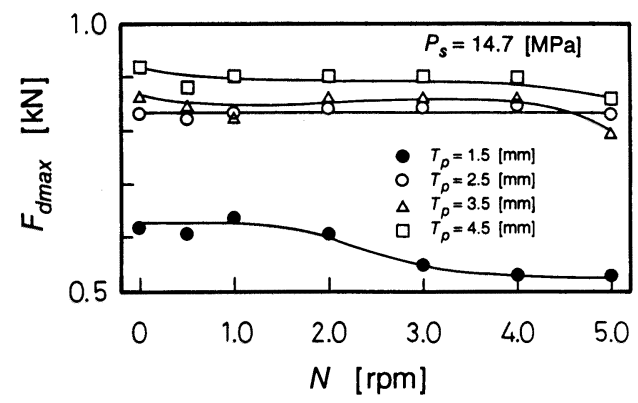

Fig. 16 Relationship between rotation speed $N$ and maximum dynamic friction force $F_{d \max }$ (Experimental data).

易くなっているためと考えられる.

\section{6 . 結論}

斜板式アキシアルピストンモータの起動・低速時に おける性能改善のための技術資料提供を図ることとし て, 特にその重要問題箇所の一つであるピストン〜シ リンダボア間の摩擦力特性を, ピストン, シリンダを 弾性体と想定した解析および実験を行って明確化する こととした，そのために(1)有限要素法による構造解析 を応用した，ピストン〜シリンダボア間静摩擦力特性 のシミュレーション解析，(2)ピストン〜シリンダボア 間静摩擦力/動摩擦力特性の, 実寸度モデルを用いた実 験による検討を併せ行った。

その結果以下の事が明らかになった。

1) ピストン〜シリンダボア間静摩擦力 $F_{s}$ の解析結 果は実験結果より高い值を示すが，定性的には一致 する。

2 ) ピストン肉厚 $T_{p}$ が小さいほどピストン後端部付 近で生じる応力集中が先端側へ位置する。

3） $T_{p}$ が大きいほど $F_{s}$ は增加するが, $T_{p}$ が最小である $T_{p}=1.5[\mathrm{~mm}]$ のピストンに関しては, 低位相角䉓囲 における $F_{s}$ が，解析ではどの $T_{p}$ のピストンよりも， 実験では $T_{p}=2.5[\mathrm{~mm}]$ のピストンょりも高い值と なる。
4 ） $T_{p}$ が小さいほどピストン〜シリンダボア間最大 動摩擦力 $F_{d \max }$ が減少する. 特に $T_{p}=1.5[\mathrm{~mm}]$ のピ ストンは, $F_{d \max }$ が最も低く, 回転速度の增加に伴う $F_{d \max }$ 減少の傾向がより明確に現れる。

なお, 今後の課題として, 種々のピストン形状と ピストン〜シリンダボア間すきま量に対応する解析 および実験，ピストン球継手部およびピストン〜シ リンダボア間油膜を考慮した解析が残されている。

最後に, 本研究の実験装置の製作および供試品の 製作に御協力頂いた帝人製機株式会社に謝意を表わ す.

1) 日比 昭, 市川常雄, 木川 治：斜板式アキシア ルピストンモータの起動・低速時の特性, 日本機 械学会論文集，43-368，(1977)，1440/1444。

2) 例えばK.-TH. Renius : Untersuchungen zur Reibung zwischen Kolben und Zylinder bei Schragscheiben-Axialkolben-Maschinen, VDI-Forschungsheft 561 (1974).

3) 小林俊一, 池谷光栄: 斜板式アキシアルピストン モータ内のピストン球部・スリッパ軸受部の弾性 静圧潤滑（第一報, 理論解析), 油圧と空気圧, 21-6 (1990)，606/612.

4 ）小林俊一, 池谷光栄: 斜板式アキシアルピストン モータ内のピストン球部・スリッパ軸受部の弾性 静圧潤滑（第二報, 流量測定), 油圧と空気圧, 21-7 (1990)，711/718.

5 ) MARC Analysis Research Corporation: MARC General Purpose Finite Element Program Vol ume A Rev. K. 2 (1983)

6) M. Ezato and M. Ikeya: Sliding Friction Characteristics between a Piston and a Cylinder for Stariting and Low-speed Conditions in the Swashplate Type Axial Piston Motor, 7th IFPS (1986), 29/37. 